\title{
THE ANALYSIS OF PREPOSITION IN AND THEIR TRANSLATION IN INDONESIAN FOUND IN “REVENGE OF SEVEN"
}

\author{
Ni Wayan Swarniti \\ Dwijendra University \\ wayanswarniti@undwi.ac.id \\ I Putu Yudi Sudarmawan \\ Dwijendra University \\ sudarmawan@undwi.ac.id \\ I Komang Dedik Susila \\ Dwijendra University \\ dediksusila@undwi.ac.id
}

\begin{abstract}
This paper focuses on the discussion of the forms of preposition in, the functions of preposition in and their translation in Indonesian. In this research, the theories used are the theory of grammar by Quirk (1973) in the book entitled A University Grammar of English and the theory of translation by Larson (1984) in the book entitled Meaning Based of Translation. For supporting theory, it was used the theory of preposition by Murthy (2003) in the book entitled Contemporary English Grammar for Scholar and Student. The data of this research were taken from the sentences that has preposition in in a novel entitled "The Revenge of Seven" by Pittacus Lore and their translation in its Indonesian version in the same title that was translated by Nur Aini. After the data were collected by underlining the sentences which are related with the topic discussed, they were classified and analyzed based on the forms or preposition in, the functions of preposition in and their translation in Indonesian. Then, the results of the analysis were presented descriptively. Based on the analysis, the forms of preposition in are as single preposition, phrase preposition and prepositional phrase. The functions of preposition in found are for indicating place and time. Preposition in was translated into target language (TL) as di, ke, dalam, pada, selama, dari, and some of preposition in were not translated.
\end{abstract}

Keywords: grammar; preposition; translation

\section{INTRODUCTION}

Translation is one of the ways for understanding a language, as Larson states that translation is basically a change of form. When we speak of the form of a language, we are referring to the actual words, phrases, clauses, sentences, paragraphs, etc, which are spoken and written. These forms are referred as the surface structure of a language (Larson, 1984). The key concept of translation is transferring the meaning from SL into TL, as the statement "Translation consists of transferring the meaning of the source language into receptor language" (Larson, 1984).

The language can be translated into spoken or written. But the problem always comes if the language are translated in written language or from one text into another text. The basic problem is translating words, phrases, clauses, sentences, paragraphs from source language into target language. The translation can be separated from using preposition in in a text, because preposition in also makes a sentence complete grammatically.

Grammar is one of the language components that should be mastered by the students in order to develop accuracy and creativity in using the language in communication (Sudarmawan, Swarniti, \& Susila, 2020). Preposition in has many various functions. For example, forming single preposition, preposition in only has functions to 
describe time and place, but more than that preposition in indicates time and preposition in indicates place can be analyzed more specific.

As phrase preposition, preposition in can be combined with some words and it is called as phrase preposition. As Murthy states that groups of words which are used as prepositions are known as phrase prepositions (Murthy, 2003).

As prepositional phrase, preposition in can be combined with prepositional complement which can make prepositional phrase. A prepositional phrase consists of a preposition followed by prepositional complement, which is characteristically a noun phrase or a WH clause or V-ing clause (Quirk, R. And Greendbaum, 1973).

For examples :

a. There are two beds in the cottage (Quirk, R. And Greendbaum, 1973).

b. Passengers should be in time for their train (Thomson, A.J. And Martinet, 1969).

c. I wanted to write a book in reference to the tribal people in Araku Valley (Murthy, 2003).

d. I'd like to see a big increase in productivity (Swan, 1980).

Preposition in has many various forms and functions. In the first example, preposition in has a form as single preposition and has a function as preposition indicates place. In this sentence, preposition in explains the position of two beds are in the cottage. In the second example, preposition in has a form as single preposition and has a function as preposition indicates time. Preposition in gives the information about the time in this sentence. In the third example, preposition in has a form as phrase preposition. Preposition in be combined with reference to. It makes one phrase preposition in reference to. In the fourth example, preposition in has a form as prepositional phrase. Preposition in be combined with productivity as prepositional complement and a noun phrase before it a big increase. The combination of preposition in and a prepositional complement productivity makes a function as postmodifier in a noun phrase.

The topic of preposition "by" has been written by Abdul Haris (2012) in his book entitled Preposition "by" and Its Translation In Indonesian (Haris, 2012). Now this paper analyzed about the topic of the preposition in and the other functions of preposition in. The research of Abdul Haris has inspired me to make this research. Abdul Haris analyzed the preposition 'by' and on this research, the forms and functions of preposition in was analyzed, because many people do not know about the forms and functions of preposition in specifically.

Based on the explanation above, this paper focuses on the discussion of the forms and functions of preposition in in the English novel entitled "The Revenge of Seven" by Pittacus Lore and their translation in its Indonesian version in the same title that was translated by Nur Aini. Hopefully, this research can be the one of knowledge sources related in the uses of preposition in in a sentence and their translation. It is helpful for this research to fill in the gaps and to be a different research (Swarniti, 2019).

\section{METHOD}

Method of research is the way to help us to solve the problems of our research and show the validity of the paper as well. It explains how the process of the research is started from collecting the data until presenting it in a paper. The method of this research is arranged as four steps, they are: determining the data source, collecting data, analyzing data, and presenting the result of the analysis.

The first step of making a research is determining the data source. In determining the data source, one English novel and its Indonesian version were used as data source. The data of this research were taken from the sentences that has preposition in in a novel entitled "The Revenge of Seven" by Pittacus Lore and their translation in its Indonesian version in the same title that was translated by Nur Aini. The reason of choosing these novels as the data source is the novels contain the data which are relevant with the topic discussed.

The second step of making a research is collecting the data. Before collecting the data for a research, the theory must be known clearly. In collecting the data, it was used observation method. Firstly, read the data source in English novel and its Indonesian version. Then, scanned and collected the data by underlining the sentences which are related 
with the topic discussed. The data which were found in the novels were rewrote in a paper and they were classified based on the forms of preposition in, the functions of preposition in and their translation in Indonesian.

The third step of making a research is analyzing the data. It is a way to analyze the data in detail. After the data collected, the data were analyzed clearly based on the theory used. In analyzing the data in this research, it was used descriptive method. First, the definition of each forms and functions of preposition in were explained. Then, each of the problem was analyzed based on the theories of grammar and translation descriptively.

The fourth step of making a research is presenting the result of the analysis. After the data were collected by using observation method and then they were analyzed by using descriptive method based on the theories used, all data are related to the topic were analyzed and served based on the scope of discussion. The method used in presenting the result of the analysis was informal method. Informal method is the method to present the result of the analysis by using the sentences to explain it.

\section{DISCUSSION}

The analysis of the data were explained in detail. The data were analyzed based on the theory used. Based on the topic discussed, there are some forms of preposition in which were found in the data source. They are preposition in forming single preposition, preposition in forming phrase preposition and preposition in forming prepositional phrase. The functions of preposition in found in the data source are for indicating place and for indicating time. Based on the analysis, preposition in was translated into target language (TL) as di, ke, dalam, pada, selama and dari. Some of preposition in found in the data source were not translated into target language, but they still have a function in source language (SL) grammatically.

The analysis of preposition in with each example were described in this chapter. All of the data here were taken from the sentences that has preposition in in the English novel entitled "The Revenge of Seven" by Pittacus Lore and their translation in its Indonesian version in the same title that was translated by Nur Aini.

\section{Preposition in Forming Single Preposition and Their Translation}

Based on the data found, here are preposition in forming single preposition. The analysis were discussed in detail in the following description.

\section{Preposition in Indicating Place and Their Translation}

Based on preposition in indicating place, there are three functions found in the data source. They are dimension, position and direction. The explanations of the analysis were described in the following description.

\section{Preposition in Translated into di}

Some data of preposition in forming single preposition were found in the data source. They were translated as $d i$ in Indonesian. The example as follows:

SL : For a moment I wonder if my friends moved me to one of the bigger beds in Nine's penthouse. (Lore, 2014)

TL : Mulanya kupikir kawankawan sudah memindahkanku ke salah satu tempat tidur besar di apartemen Nomor Sembilan. (Aini, 2015)

The example above is preposition in forming single preposition. Preposition in in source language (SL) was translated as $d i$ in target language (TL) literally. In the example, preposition in has a function as preposition indicates place. It also denotes as preposition indicates place in Indonesian. In this sentence, preposition in denotes as dimension. With preposition in, Nine's penthouse becomes the three dimensional object which in reality it is, though preposition in is capable of being used with objects which are essentially twodimensional.

\section{Preposition in Translated into ke}

Here, preposition in which is translated as $k e$ has a form as single preposition. The example and the explanation is in the following description.

SL : He shouts in my face. (Lore, 2014)

TL : Dia berseru ke wajahku. (Aini, 2015) 
In the example, preposition in has a form as single preposition. It also was translated into $k e$ in Indonesian. Preposition in in the example expresses preposition indicate place. It was denoted as direction. It means preposition in in this example describes about the movement with respect to a destination.where he shouts. In a cause and effect relationship, direction is as a cause. So, the direction of where he shouts is in my face and it was indicated by preposition in. Besides, preposition in in this sentence was translated into target language (TL) as $k e$.

\section{Preposition in Translated into dalam}

From the data source, it was found some data which translated into target language (TL) as dalam. The example also have a form as single preposition. Here is the explanation of it.

SL : Eight floats over the Sanctuary's well in a column of unleashed energy. (Lore, 2014)

TL : Nomor Delapan melayang di atas sumur Suaka dalam pilar energi tak terkekang. (Aini, 2015)

Based on the example, preposition in here has a form as single preposition. The function of this data is as preposition for indicating place. Preposition in in this sentence denotes as dimension. With preposition in, a column of unleashed energy becomes the three dimensional object which in reality it is. Preposition in in source language was translated into target language (TL) as dalam in this example. Actually, dalam is real meaning of preposition $i n$. It can be seen in a dictionary.

\section{Preposition in Translated into dari}

As single preposition, preposition in was translated into target language (TL) as dari. The example and the analysis of it as follows:

SL : But then a pain starts up in my shoulder where I was stabbed. (Lore, 2014)

TL : Namun, rasa sakit mulai menjalar dari bahuku yang terluka. (Aini, 2015)

Preposition in in the example was translated into Indonesian as dari. The form of preposition in here is as a single preposition. Besides, it also has a function in source language (SL) as preposition for indicating place. In Indonesian, the function of dari also is as preposition indicates place. Preposition in here was denoted as position. The position of $a$ pain starts up was explained by preposition in in this sentence. The position of where $a$ pain starts up is in my shoulder.

\section{Preposition in Untranslated}

Not all of preposition in in the sentences found was translated into target language clearly. Here, there are preposition in in these examples were not translated into Indonesian. Grammatically, preposition in here complete these sentences and it has a meaning in source language (SL).

SL : A soldier in this war who's doing what needs to be done. (Lore, 2014)

TL : Prajurit perang yang tahu harus berbuat apa. (Aini, 2015)

From the example above, it can be seen that preposition in in the example were not translated into target language (TL), but they still have a meaning in source language to complete it grammatically. All of the examples has a form as single preposition. In the example above, preposition in in this sentence has a function as preposition indicates place. It denotes as position, because the position of $a$ soldier was described by preposition in. So, the position of a soldier is in this war.

\section{Preposition in Indicating Time and Their Translation}

Based on the theory in above, there are two functions of preposition in indicates time. They are point of time and period of time. The data and the analysis were discussed in the following explanations.

\section{Preposition in Translated into di}

In the data source, there are some preposition in were found which indicate as time, but it was translated into $d i$ in Indonesian. Normally, the word $d i$ in Indonesian is used to indicate place not time. The example as follows:

SL : Some unlucky underling is trying to call Setrakus Ra right in the middle of his big day. (Lore, 2014)

TL : Satu anak buah malang berusaha menghubungi Setrakus 
Ra tepat di hari besarnya. (Aini, 2015)

Based on the analysis preposition in in this sentence has a form as single preposition. Different with the previous examples, preposition in in this example has a function as preposition indicates time and it has same function in Indonesian as preposition indicates time. Preposition in in this sentence denotes point of time. It means the time in this example is really time. The time explains one time which describes the middle of his big day in this sentence. The time can not be changed. Preposition in in source language (SL) was translated into target language (TL) as di. It was translated literally.

\section{Preposition in Translated into pada}

Based on the data found, the data here have a form as single preposition and have a function for indicating time. Generally, preposition in which indicates as time in English will be translated into pada in Indonesian. Here is the example of it.

SL : None of the others have Legacies that leave them traumatized in the morning. (Lore, 2014)

TL : Garde lain tidak punya Pusaka yang membuat mereka trauma pada pagi hari. (Aini, 2015)

In the example, the form of preposition in here is as single preposition. Preposition in in source language (SL) was translated into pada in target language (TL). In the example, it can be seen that preposition in has a function as preposition indicates time. In Indonesian, it also has a function as preposition indicates time. In this case, preposition in denotes period of time. Period of time describes about the whole time of the morning in the sentence.

\section{Preposition in Translated into selama}

Besides, preposition in forming single preposition in the data source also was translated into selama in Indonesian. In Indonesian the word selama is used for indicating time. The example and the analysis as follows:

SL : In the years we've spent on the run, the Mogadorians have gotten too far ahead, become too entrenched in the military, government and even the media. (Lore, 2014)

TL : Selama bertahun-tahun ini, saat kami melarikan diri Mogadorian telah jauh di depan, sangat dilindungi militer, pemerintah, bahkan media. (Aini, 2015)

Preposition in also was translated into target language (TL) as selama. Here, the function of preposition in was expressed as preposition indicates time. In this sentence, preposition in denotes as period of time. Not just in source language (SL), preposition in in target language (TL) also has same function as period of time, because selama in target language (TL) or in Indonesian describes about period of time of the years. Actually, period of time means the whole time of the years in this sentence. In the years in source language (SL) was translated into target language (TL) as selama bertahun-tahun ini. So, in the years means the whole time of the years in this sentence.

\section{Preposition in Untranslated}

Not all of preposition in in a sentence found in the data source was translated into target language (TL). There are preposition in in these examples were not translated into Indonesian, but grammatically preposition in here completes these sentence. In the following description, it was discussed.

SL : In that time, I was unconscious, the whole world changed. (Lore, 2014)

TL : Saat aku tidak sadarkan diri itu, segalanya berubah. (Aini, 2015)

From the example above, it can be seen that preposition in was not translated into target language. Although preposition in was not translated into target language, but it still makes the sentence in source language (SL) complete grammatically. Based on the analysis, these data also have a form as single preposition. In the first examples, preposition in here has a function as preposition indicates time. It denotes point of time. Point of time means preposition in denotes just the really time. The 
time can not be changed. It shows one time of the situation.

\section{Preposition in Forming Phrase Preposition and Their Translation}

The other form of preposition in found in the data source is as phrase preposition. It can be indicated with groups of words which are used as prepositions. The example as follows:

SL : In addition to the electrodes, someone has cleaned the blood off him (Lore, 2014)

TL : Selain elektroda tersebut, noda darah di tubuh Nomor Delapan sudah dibersihkan. (Aini, 2015)

In this example, preposition in was combined with the words addition to in source language (SL). It makes a phrase preposition. In source language (SL) in addition to was translated into target language (TL) as selain. Unit shifts more discuss about the difference form in SL text into TL text, especially from word into phrase or phrase into word. In source language (SL), in addition to was a phrase, but in target language (TL), it was translated into a word selain.

\section{Preposition in Forming Prepositional Phrase and Their Translation}

Besides single preposition and phrase preposition, the other form of preposition in is as prepositional phrase. Based on the analysis, they were combined with a prepositional complement. Here, preposition in forming prepositional phrase has some functions syntactically. They are adjunct, disjunct, postmodifier in a noun phrase, complementation of a verb and complementation of an adjective. They were translated into target language (TL) idiomatically.

\section{Preposition in Indicating Adjunct}

Based on the theory used, there are some syntactic functions of preposition in forming prepositional phrase. One of them is as adjunct. Here is the example of it.

SL : Setrakus Ra already took care of them, sending the Mog technicians away so that we could greet this new arrival in private (Lore, 2014)

TL : Setrakus Ra sudah mengurus masalah itu. Di telah memerintahkan para teknisi Mogadorian pergi sehingga kami dapat menyambut tamu tersebut secara pribadi. (Aini, 2015)

Based on the example above, preposition in here have a form as prepositional phrase. They were analysed together with a prepositional complement. In the first example, preposition in in source language (SL) was seen like this data has a translation into target language (TL) as secara, but in fact it was translated idiomatically. The translation of preposition in was referred by a prepositional complement private. So, preposition in in this sentence also has a form in prepositional phrase. It also was indicated as adjunct. This sentence can be said complete with or without in private.

\section{Preposition in Indicating Disjunct}

The other function of preposition in as prepositional phrase is as disjunct. In the following description is the example of it.

SL : In answer, the ship's engine begins to vibrate beneath our feet. (Lore, 2014)

TL : Sebagai jawaban, mesin pesawat dibawah kami mulai bergetar. (Aini, 2015)

The form of preposition in in this sentence is as prepositional phrase. In the example, it was look like that it has a translation as sebagai in Indonesian, but the translation of preposition in was referred by a prepositional complement answer. Preposition in here denotes as disjunct. Preposition in in this sentence was combined with answer. It makes a prepositional phrase. In answer and the sentence the ship's engine begins to vibrate beneath our feet were separated by comma in this example.

\section{Preposition in Indicating Postmodifier in a Noun Phrase}

As prepositional phrase, preposition in also can be indicated as postmodifier in a noun phrase. The example as follows:

SL : My shield deploys, expanding in the usual umbrella-like way, but immediately turns black and 
brittle when the General's blast hits. (Lore, 2014)

TL : Perisaiku membuka, bergerak melebar bagai payung seperti biasanya, tapi sekonyong-konyong berubah jadi hitam dan rapuh begini dihantam tembakan sang Jenderal. (Aini, 2015)

In the example, it was like preposition in here has a translation as bagai in target language (TL), but the translation of preposition in was referred by a prepositional complement the usual umbrella-like way. It was resnalated idiomatically. It also has a function as postmodifier in a noun phrase. Preposition in here explains the usual umbrella-like way in this sentence. The usual umbrella-like way is called prepositional complement. So the combination of preposition in and prepositional complement make a prepositional phrase.

\section{Preposition in Indicating Complementation of Verb}

From the data found in data source, some prepositional phrases can be indicated as complementation of a verb. Here is the example of it.

SL : He doesn't seem at all interested in her. (Lore, 2014)

TL : Sepertinya dia sama sekali tidak tertarik kepada Walker. (Aini, 2015)

From the example above, it was like preposition in here has a translation in Indonesian as kepada, but the translation of preposition in was referred by a prepositional complement her. It was translated based on its meaning. Besides, preposition in in this example also has a function in source language (SL) as a complementation of a verb. Preposition in here completed the verb interested.

\section{Preposition in Indicating Complementation of An Adjective}

The last function of preposition in forming prepositional phrase is as complementation of an adjective. Here is the example of it.

SL : He looks lost in memory (Lore, 2014)

TL : Dia seperti sedang mengingat masa lalu (Aini, 2015)
In the example, the form of preposition in here is as prepositional phrase. In this sentence, an adjective lost be combined with a preposition in. The combination of it makes one prepositional phrase indicates as complementation of an adjective. The data here was look like preposition in was translated into target language (TL) as dalam, but the translation of preposition in was referred by a prepositional complement memory and the adjective lost. So, it was translated based on their meaning in source language (SL).

\section{CONCLUSION}

After analyzing some data above, some conclusions were made. All the forms of preposition in in the English novel have analyzed. The forms of preposition in found in the English novel entitled "The Revenge of Seven" by Pittacus Lore were as single preposition, phrase preposition and prepositional phrase.

Based on the data found, the functions of preposition in are as first, preposition in forming single preposition was divided into preposition in indicates place and time. Preposition in indicates place was denoted as dimension, position and direction. Preposition in indicates time was denoted as point of time and period of time. Second, preposition in was indicated as phrase preposition. Third, preposition in forming prepositional phrase was indicated as adjunct, disjunct, postmodifier in a noun phrase, complementation of a verb and complementation of an adjective.

Based on the analysis above, the translation of preposition in were taken from its Indonesian version novel in the same title that was translated by Nur Aini. First, preposition in forming single preposition was translated into target language (TL) as di, ke, dalam, pada, selama, dari and some of them were not translated. Second, preposition in forming phrase preposition was not translated into target language clearly. But it still makes the sentence complete grammatically. Third, preposition in forming prepositional phrase was not translated into target language (TL) clearly, but the translation of preposition in was referred by a prepositional complement. Grammatically they still have functions in source language (SL) syntactically. Most of the data found were 
translated idiomatically. Translation shifts found in some data was only unit shifts. The shifts of unit found were from a phrase to a word and from a word to a phrase.

\section{REFERENCES}

Aini, N. (2015). The Revenge of Seven. Bandung: PT. Mizan Fantasi.

Haris, A. (2012). Prepositional phrase "by" And Its Translation In Indonesian. Warmadewa University.

Larson, M. . (1984). Meaning Based Treanslation. New York: University Press of America.

Lore, P. (2014). The Revenge of Seven. New York: Harper Collins Publishers.

Murthy, J. . (2003). Contemporary English Grammar for Scholar and Student. New Delhi: Book Palace.
Quirk, R. And Greendbaum, S. (1973). A University Grammar of English. London: Longman Group Ltd.

Sudarmawan, I. P. Y., Swarniti, N. W., \& Susila, I. K. M. (2020). The Mistake BusterTechnique for Sentence. LEJU (Language and Education Journal Undiksha), 3(1), 7-14.

Swan, M. (1980). Practical English Usage. New York: Oxford University Press.

Swarniti, N. W. (2019). The Translation Procedures of Bible Translation, 5(2), 187-196.

https://doi.org/10.22225/jr.5.2.1277.187196

Thomson, A.J. And Martinet, A. . (1969). A Practical English Grammar. New York: Oxford University Press. 